\title{
TARGETED CHANGE IN THE MENTALITY OF COMMUNITIES THROUGH TRANSFORMATIVE ADULT LEARNING
}

\author{
Dmytro Dzvinchuk, Victor Petrenko, Mariana Orliv, Andriy Mazak, Iryna Ozminska \\ Ivano-Frankivs National Technical University of Oil and Gas \\ morliv@ukr.net
}

\begin{abstract}
The relevance of the study is driven by the need to transform the mentality of human resources of Ukraine to introduce the reform of decentralisation of power and to create capable amalgamated territorial communities. The paper explains the specifics of the implementation of the programmes of transformative adult learning for a targeted change in the mentality of communities. For this purpose, the reengineering programme "Aware Residents is a Strong Community" was developed (using the theories of transformative adult learning, institutional matrices and progressive capitalism) and carried out among 200 local leaders and 800 residents of territories where the Kosmatska and Yabluniv ATCs were to be created, according to the Government's Perspective Plan. The content of the programme was justified, and the effectiveness of its implementation was proved based on the results of the preproject and follow-up sociological surveys through questioning all categories of adults with a sample size of 400 people selected using the methods of sociological analysis. The research revealed that the transformative adult learning, which involves a duality approach of individual and collective learning and community engagement approach, is an effective tool for introducing targeted changes in the human mentality according to the criteria of the Western institutional matrix. Therefore the findings can be used when implementing educational projects and programmes aimed at the reformation of public administration and the introduction of democratic governance.
\end{abstract}

Keywords: transformative adult learning; mentality; reengineering programme; amalgamated territorial communities; aware residents.

\section{Introduction}

The process of large-scale transformation of the local self-government system in Ukraine started in 2014 in accordance with the Concept of Reforming Local Self-Government and Territorial Structure of Power approved by the Government (Cabinet of Ministers of Ukraine, 2014). The implementation of the decentralisation project requires radical institutional, structural and managerial changes in the living arrangements of territorial communities, as well as a targeted modification of the mentality of their human resources with a reorientation to the modern worldview values of an intellectualised and globalised economy. Therefore, many international organisations, programmes and national foundations (including the United Nations Development Program, the Friedrich Naumann Foundation for Freedom, Friedrich Ebert Stiftung, the US Agency for International Development, the Eastern Europe Foundation, U-LEAD with Europe, the European Science Foundation, the International Renaissance Foundation, the International Visegrad Fund, Education for Democracy Foundation, etc.) fund educational projects focused on supporting an active, diverse and open civil society that is determined to introduce democratic governance in Ukraine.

The need to change the set of beliefs among the population of the communities determines the relevance of research and evaluation of already existing mindsets of community residents with the view of their further consideration in the process of implementation of systemic reforms. In this regard, a challenging task is to analyse and assess the readiness of human resources of territorial communities for changes related to the democratisation of governance and decentralisation of power, as well as the development and implementation of programmes which provide the necessary transformation of the mentality of the territorial communities through transformative adult learning. This task should be addressed in the context of the integration of Ukraine into the global and the European communities of developed countries.

The study of the problems of decentralisation of power in Ukraine is a new trend in the national science (Poliakova, 2017). However, public administration experts (Radchenko, \& Molodtsov, 2018) found out that decentralised social relations in general and political-administrative in particular cannot be built while maintaining the existing institutional order, since it hinders the formation of a new people's mentality and transition to new relationships between central and local authorities. Exploring the socio-philosophical problems of the national economy in the age of globalisation, Hlushko (2017) emphasised that "Mental transformations are the most complex ones and always require a re-evaluation of basic social values and revision of the worldviews of the individual and society as a whole" (p. 308). However, except for some studies (e.g., by Petrenko et al., 2017; Panasiuk et al., 2018), neither the problem of the necessity of changes

(C) Dmytro Dzvinchuk, Victor Petrenko, Mariana Orliv, Andriy Mazak, Iryna Ozminska.2020. Published by Igor Sikorsky Kyiv Polytechnic Institute. This is an Open Access article distributed under the terms of the licence CC BY 4.0 
in the mentality of human resources, nor the problem of motivation and ability of human resources to change have been paid enough attention in Ukrainian scientific researches.

The problem of the dominant mentality of the Ukrainian population, which was shaped by the long-term influence of patterns of the Eastern institutional matrix (unitary centralised political system, redistributive economy and communitarian ideology) complicates the decentralisation of power and creation of the amalgamated territorial communities (ATCs) with new mandates, functions, and resources. This opinion is shared by Baran (2015), Dancheva (2015) and the experts of the Press Center of the Government Initiative "Decentralization of Power" (2017) on the basis of the results of evaluating the already implemented transformations, overcoming the resistance of people and related changes in their attitudes and opinions. In this context, it is appropriate to cite Winston Churchill (1941), who defined civilisation as "a society based upon the opinion of civilians" (p. 45). Therefore, the main obstacles for the changes, which occur in the living arrangements and in the functioning of new territorial socio-economic communities, are the conservative values and beliefs preserved by the generations of community residents. Thus, the transition of society or any of its components to the institutional principles of the Western-type matrix (federal decentralised political system, market economy and individualistic ideology) cannot be achieved without changing the mentality of people as one of the main determinants of their behaviour. At the same time, it is impossible to change citizens' opinions without adequate changes in the mechanisms, technologies and tools of public administration, as well as without new knowledge and experience, which senior executives and officials of local self-government bodies often lack. The population of ATCs (the number of which in January 2020 exceeded 980 and continues to grow), is also lacking similar knowledge and experience. This problem is partially solved through organising the training and consulting support for the decentralisation processes by various international technical assistance projects, focused mainly on training senior executives, deputies and officials of local self-government bodies (Tkachuk, 2017; Lelechenko et al., 2017). At the same time, the individual and collective mentality of ordinary citizens remains unaddressed. This is a significant gap as a public discussion is an important stage in local government decision-making, in particular regarding the amalgamation of territorial communities.

It is obvious that the complex processes of overhaul and reassessment of worldview principles by the Ukrainian citizens, necessitate making unconventional decisions, using educational programmes and techniques of large-scale adult learning, which have not yet been given due attention in Ukraine. However, in scientific discourse, there are quite a few researches (for instance, by Janiunaite \& Petraite, 2015; Dzvinchuk \& Petrenko, 2018; Pylynskyi, 2018; Tanasiichuk, 2019) on substantiating effective approaches to the education and retraining of adult population of ATCs aimed at targeted changes of individual and collective mentality, identification and use of appropriate techniques, setting of goals and tasks. It is also obvious that in modern intellectual society the "opinion of the citizens" is difficult to change through dictating or imposing innovative concepts and ideas, life positions and values, feelings and evaluations that are incompatible with already existing attitudes. This is reflected in the emergence of the so-called "path dependence problem" - a problem of past experience (Putnam, 1993). It prevents individuals or communities from abandoning past ideas in order to set other benchmarks and goals and achieve better results.

The literature lacks first-hand stories from the individuals who have personally experienced transformative learning as the dominant theory in adult education (Biasin, 2018; Gorbunova, 2015; Kroth \& Cranton, 2014). Proceeding from this, a group of scientists from the Department of Public Administration and Management of Ivano-Frankivsk National Technical University of Oil and Gas (IFNTUOG) with the assistance of Ivano-Frankivsk Regional Public Organisation "Social Amnesty" (IFRPO "Social Amnesty") launched a research programme in order to improve the management of the processes of formation of capable ATCs and their further development based on transformative adult learning focused on the patterns of the Western institutional matrix.

The purpose of the article is to demonstrate and explain how the theory of transformative adult learning can be used in practice for achievement of targeted change in the mentality of communities aimed to promote democratic governance in Ukraine, in particular, the reform of decentralisation of power and voluntary amalgamation of territorial communities.

\section{Methods}

The research was carried out as a part of the "Aware Residents is a Strong Community" project. The purpose of the project was to assist the residents of the potential Kosmatska and Yabluniv ATCs in IvanoFrankivsk region to implement key ideas of decentralisation in order to create communities that are able to take responsibility for their further functioning and development. The project was realised through the implementation of the programme of community development reengineering aimed at changing the human 
resource mentality. Its methodology was based on systematic and situational approaches, the theory of transformative adult learning (Mezirow, 1997), duality approach of individual and collective transformative learning (Kennedy-Reid, 2014), community engagement approach (Davis, Kliewer \& Nicolaides, 2017), theories of institutional matrices (Kirdina, 2014; Radchenko \& Molodtsov, 2018) and progressive capitalism (Stiglitz, 2019; Dzvinchuk et al., 2019).

The programme of community development reengineering was carried out at four stages:

(1) the pre-project sociological survey via questioning all categories of adults in the territories where, according to the Government's Perspective Plan (Monitoring, 2019), the Kosmatska and Yabluniv ATCs are to be created;

(2) preparation and distribution of educational and methodological materials, creation of web pages on the websites of local self-government bodies as well as sections in local newspapers on the issues of amalgamation of territorial communities;

(3) implementation of training activities for local leaders and community residents, the content and forms of which are determined with due consideration of the results of the pre-project sociological survey;

(4) follow-up sociological survey in order to identify the results of the programme implementation and outline further actions.

At stages 1 and 4 in the pre-project and follow-up sociological surveys, the methods of questionnaire and statistical analysis were used. The researchers of the Department of Public Administration and Management of IFNTUOG designed a questionnaire on respondents' knowledge, awareness, integration, ability and motivation regarding the decentralisation reform and community amalgamation. The questionnaire consisted of 20 questions of which 17 were close-ended questions with answer options like "I don't know", "hard to answer", "I don't care", "I don't support the idea", "I don't believe" etc. and 3 openended questions about the conditions and stages of voluntary amalgamation of territorial communities.

The participants of the surveys were selected on the basis of the methods of sociological analysis with due account for the demographic and statistical indicators of the composition of the population, with a total of 25,168 people. A representative survey sample of 400 people (192 men and 208 women) was based on the official data provided by the Head Department of Statistics in Ivano-Frankivsk region and on the following four characteristics: gender, age, education and field of activity. All participants gave informed consent for participating in the study and sharing the information about the results of sociological research with stakeholders.

The age characteristics of male respondents sample were as follows: 30 persons were aged 18-29 years, 75 persons were aged 30-49 years, 87 persons were aged 50 years and over. Of the 192 male respondents, 18 were local self-government officers, 59 were agricultural workers, 20 were workers, 50 were pensioners, 8 were students and 37 were representatives of other professions. As for the educational background, 52 persons had elementary or lower secondary education, 69 completed secondary education, 58 had secondary specialised or partially completed higher education, and 13 had higher education.

The age characteristics of female respondents were as follows: 35 persons were aged 18-29, 72 persons were aged 30-49 years, 101 persons were aged 50 years and over. Of the 208 respondents, 20 females were local self-government officers, 75 - were agricultural workers, 15 - were workers, 60 - were pensioners, 12 - were students, and 26 - were representatives of other professions. As for the educational background, 48 female respondents had elementary or incomplete secondary education, 80 females had secondary education, 62 persons had secondary specialised or incomplete higher education, 18 had higher education.

The answers to the questionnaire were divided into three groups depending on the respondents' age: 1829 years, 30-49 years, and 50 years and over. The voting qualifications of Ukraine were also taken into account, i. e. the voter must be 18 years of age or over on the day of the election, a resident of a community and eligible to vote.

Based on the results of the pre-project $\left(\mathrm{R}_{1}\right)$ and follow-up $\left(\mathrm{R}_{2}\right)$ sociological surveys among three age groups, the proportion of respondents (\%) who were aware of the issues of decentralisation reform (by five criteria in Table 1) and supported its implementation (by seven criteria in Table 2) was determined. The average indicators for the entire sample without age distinction $\left(\overline{\mathrm{R}}_{1}\right),\left(\overline{\mathrm{R}}_{2}\right)$ were used to predict the probable overall outcomes of community voting on the creation of capable Kosmatska and Yabluniv territorial communities. After the implementation of the programme of community development reengineering, positive changes in respondents' knowledge and attitudes were defined in three age categories $(\Delta R)$ and by sample as a whole $(\Delta \bar{R})$.

The development of the content of educational and methodological materials, web pages and publications on stage 2 was aimed at making the residents aware of the fact that changes in the social organisation of their life, recommended by science and experience of developed countries, are able to unite people to cooperate for the common good. Therefore, the methodical guidelines entitled "Aware Residents is 
a Strong Community" (Petrenko, Struk \& Kushniriuk, 2016) were prepared. The guidelines covered problems of the administrative and territorial reform in Ukraine, the foreign experience of decentralisation and local reform, cooperation among community residents who will create an ATC, the socio-economic development of the ATCs, and leadership development at the local level by the system-oriented approach.

At stage 3 the guidelines were used in the training process of local leaders (200 people), which was held in the form of individual and group discussions, roundtables, seminars and skills workshops, as well as awareness-raising activities with a community population (800 people) organised in the form of public hearings and discussions. The technology of the programme implementation was based on the results of the research which was carried out by the scientists of the Department of Public Administration and Management of IFNTUOG and dealt with the formation of a structural and functional model of ATC (Panasiuk, 2018), improvements in the technology of mindset reengineering for implementation of changes (Petrenko et al., 2017) and other related topics. The choice is explained by the fact that the learning is the process in which the learners generate meaning and construct understanding on the grounds of their individual knowledge and experience (Jin, 2017). The training activities were realised in a pervasive-learning environment, which, according to Shubina and Kulakli (2019), is important both for improving cognitive processes and for increasing intrinsic motivation.

\section{Results}

The readiness of human resources for the formation of ATCs in terms of knowledge, awareness, integration, ability and motivation was evaluated at the stage of the pre-project sociological survey. The results of the survey showed an insufficient level of awareness among the residents, concerning voluntary amalgamation of territorial communities, the presence of the process-related demotivating ideas, as well as the disintegration of opinions of the population and the low level of differentiation of reliable and false information. On the basis of these data, it was found out that the programme of training activities should change the mentality of community residents and local self-government officials and raise their knowledge and awareness of the following issues: goals, objectives and prospects of voluntary amalgamation; work peculiarities in the context of new conditions with new mandate and resources; opportunities for the community residents to participate in territory planning, budget planning and redevelopment of community territories.

The training activities were held by the experts of the Department of Public Administration and Management of IFNTUOG and members of IFRPO "Social Amnesty". The result is seen not only in increasing knowledge and awareness of the respondents about the implementation of decentralisation reform and amalgamation of territorial communities but also in changing their attitude to these processes. It is important to emphasise that the implementation of training activities provided positive changes by all criteria which indicate respondents' knowledge of the reform (Table 1) and attitudes to it (Table 2).

Table 1. Summarised results of the pre-project $\left(\mathbf{R}_{1}\right)$ and follow-up $\left(\mathbf{R}_{2}\right)$ surveys which indicate the increase of respondents' knowledge of the reform

\begin{tabular}{|c|c|c|c|c|c|}
\hline $\begin{array}{l}\text { Criteria by which the } \\
\text { respondents' knowledge level } \\
\text { was analysed }\end{array}$ & $\begin{array}{l}\text { Age } \\
\text { (years) }\end{array}$ & $\begin{array}{l}\mathbf{R}_{1} \\
(\%)\end{array}$ & $\begin{array}{l}\mathbf{R}_{2} \\
(\%)\end{array}$ & $\begin{array}{l}\Delta \mathbf{R} \\
(\%)\end{array}$ & $\begin{array}{l}\text { Average indicators } \overline{\mathbf{R}}_{1}, \overline{\mathbf{R}}_{2}, \Delta \overline{\mathbf{R}} \text { for the entire sample withou } \\
\text { age distinction and comments on them }\end{array}$ \\
\hline \multirow{3}{*}{$\begin{array}{l}\text { Knowledge of the problems of } \\
\text { local self-government } \\
\text { development }\end{array}$} & & & & & \multirow{3}{*}{$\begin{array}{l}\text { The proportion of respondents who studied these issues } \\
\text { significantly increased from } 16 \% \text { to } 33.5 \%(+17.5 \%) \text {. }\end{array}$} \\
\hline & $30-49$ & & & & \\
\hline & & & & & \\
\hline \multirow{3}{*}{$\begin{array}{l}\text { Knowledge of changes to the } \\
\text { Constitution of Ukraine } \\
\text { regarding decentralisation }\end{array}$} & & & & & \multirow{3}{*}{$\begin{array}{l}\text { At the stage of the pre-project survey, } 34.5 \% \text { of the respondents } \\
\text { were familiar with the changes, and after the project } \\
\text { implementation, } 41.1 \% \text { were able to differentiate between reliable } \\
\text { and false information. }\end{array}$} \\
\hline & $30-49$ & & & & \\
\hline & & & & & \\
\hline \multirow{3}{*}{$\begin{array}{l}\text { Knowledge of the issues } \\
\text { regarding community } \\
\text { amalgamation }\end{array}$} & & & & & \multirow{3}{*}{$\begin{array}{l}\text { The proportion of aware respondents increased from } 55.2 \% \text { to } \\
74 \%(+18.8 \%) \text {. }\end{array}$} \\
\hline & -49 & & 75 & & \\
\hline & & & 64 & & \\
\hline \multirow{3}{*}{$\begin{array}{l}\text { Understanding the } \\
\text { characteristics of a capable } \\
\text { community }\end{array}$} & & & & & \multirow{3}{*}{$\begin{array}{l}\text { The proportion of respondents who can identify a capable } \\
\text { territorial community based on an analysis of its characteristics } \\
\text { increased from } 47.3 \% \text { to } 70.2 \%(+22.9) \text {. }\end{array}$} \\
\hline & -49 & & 4 & & \\
\hline & & & & & \\
\hline \multirow{3}{*}{$\begin{array}{l}\text { Identification of bodies who } \\
\text { uphold the interests of the } \\
\text { community }\end{array}$} & & & & & \multirow{3}{*}{$\begin{array}{l}\text { At the stage of the pre-project survey, the average indicator was } \\
\text { high }(80.3 \%) \text {, so its change by } 10.3 \% \text { does not have a significant } \\
\text { effect on the performance indicator. }\end{array}$} \\
\hline & $30-49$ & 77. & 89.1 & 11. & \\
\hline & & 81.9 & 85.9 & & \\
\hline
\end{tabular}


In addition to the quantitative indicators and their average values given in Table 1, the answers to the open-ended questions of the survey allow us to state that the level of insufficient knowledge of the conditions and stages of voluntary amalgamation of territorial communities at the stage of the pre-project survey changed into a high level of awareness of the process of the decentralisation reform at the stage of the follow-up survey. At the same time, the level of awareness of the respondents who receive information from the Internet (aged 18-49) is higher than the level of awareness of the respondents who rely more on public opinion (aged 50 and over).

At the stage of the follow-up survey, answers like "hard to answer", "I don't care," "I don't support the idea", "I don't believe" and "I don't know" were found in the questionnaire 1.8 times less frequently than at the pre-project stage, which reflects the tangible mental changes in the consciousness of the community residents in the process of implementing the programme.

Table 2. Summarised results of the pre-project $\left(\mathbf{R}_{1}\right)$ and follow-up $\left(\mathbf{R}_{2}\right)$ surveys, which indicate a positive change in the respondents' attitude to the reform

\begin{tabular}{|c|c|c|c|c|c|}
\hline $\begin{array}{l}\text { Criteria by which } \\
\text { respondents' attitude } \\
\text { changed }\end{array}$ & $\begin{array}{l}\text { Age } \\
\text { (years) }\end{array}$ & $\begin{array}{l}\mathbf{R}_{1} \\
(\%)\end{array}$ & $\begin{array}{l}\mathbf{R}_{2} \\
(\%)\end{array}$ & $\begin{array}{l}\Delta \mathbf{R} \\
(\%)\end{array}$ & $\begin{array}{l}\text { Average indicators } \overline{\mathbf{R}}_{1}, \overline{\mathbf{R}}_{2}, \Delta \overline{\mathbf{R}} \text { for the entire sample withou } \\
\text { age distinction and comments on them }\end{array}$ \\
\hline & $18-29$ & 30.8 & 76.2 & 45.4 & \multirow{3}{*}{$\begin{array}{l}\text { A clear understanding of the essence of decentralisation, its } \\
\text { perception as a process of democratisation of power and } \\
\text { governance without ineffective bureaucratic procedures has } \\
\text { increased on average from } 38.8 \% \text { to } 62.6 \%(+23.8) \text {. }\end{array}$} \\
\hline & $30-49$ & 40.8 & 56.1 & 5.5 & \\
\hline & $50+$ & 4.7 & 55.6 & 0.9 & \\
\hline \multirow{3}{*}{$\begin{array}{l}\text { Awareness of the perspectives } \\
\text { of development of local self- } \\
\text { government }\end{array}$} & & & & & \multirow{3}{*}{$\begin{array}{l}\text { The proportion of respondents who believe that the communities } \\
\text { will receive additional resources has increased from } 16.3 \% \text { to } \\
54.3 \%(+38 \%) \text {. }\end{array}$} \\
\hline & $30-49$ & & 5.1 & & \\
\hline & $50+$ & 5 & 29.6 & 3.1 & \\
\hline \multirow{3}{*}{$\begin{array}{l}\text { Comprehension of the } \\
\text { objective reasons for } \\
\text { introducing changes to the } \\
\text { Constitution of Ukraine }\end{array}$} & & & & & \multirow{3}{*}{$\begin{array}{l}\text { The proportion of respondents who attribute the changes to the } \\
\text { Constitution exclusively to the need for decentralisation of power } \\
\text { has increased from } 26.4 \% \text { to } 36.6 \%(+10.2 \%) \text {. }\end{array}$} \\
\hline & $30-49$ & & 4.1 & & \\
\hline & $50+$ & & & & \\
\hline & $18-29$ & & & & \multirow{3}{*}{$\begin{array}{l}\text { This indicator was quite high }(70.9 \%) \text {, therefore its value } \\
\text { increased only by } 0.4 \% \text {. This shows the support for the } \\
\text { government-chosen path of voluntary amalgamation of } \\
\text { communities. }\end{array}$} \\
\hline & $30-49$ & 72.8 & 74.9 & & \\
\hline & $50+$ & & & & \\
\hline \multirow{3}{*}{$\begin{array}{l}\text { Reliance on the information } \\
\text { about the substantial growth of } \\
\text { ATC budget funding }\end{array}$} & $18-29$ & & & & \multirow{3}{*}{$\begin{array}{l}\text { The level of trust increased from } 24.1 \% \text { to } 47 \% \\
(+22.9 \%) \text {, indicating a significant rise in motivation to } \\
\text { amalgamate territorial communities. }\end{array}$} \\
\hline & $30-49$ & 7.2 & & 1.8 & \\
\hline & $50+$ & & 44.2 & & \\
\hline \multirow{3}{*}{$\begin{array}{l}\text { Approval of the state support } \\
\text { for voluntary community } \\
\text { amalgamation }\end{array}$} & & & & & \multirow{3}{*}{$\begin{array}{l}\text { Approval of the integrity of informative, organisational, } \\
\text { methodological and financial support of the state has increased } \\
\text { from } 19 \% \text { to } 55 \%(+36 \%) \text {. }\end{array}$} \\
\hline & $30-49$ & & 3.4 & & \\
\hline & $50+$ & 9.6 & 53 & 3.4 & \\
\hline \multirow[t]{3}{*}{$\begin{array}{l}\text { Individual support for } \\
\text { community amalgamation }\end{array}$} & $18-29$ & 24.6 & 61.4 & 36.8 & \multirow{3}{*}{$\begin{array}{l}\text { The key performance indicator of the programme shows the } \\
\text { growth of the support level from } 27.4 \% \text { to } 60.6 \%(+33.2 \%) \text {. The } \\
\text { result of the programme, therefore, demonstrates that a prevailing } \\
\text { majority of respondents support community amalgamation. }\end{array}$} \\
\hline & $30-49$ & 19.8 & 61.3 & 41.5 & \\
\hline & $50+$ & 37.8 & 58.9 & 21.1 & \\
\hline
\end{tabular}

The findings of the survey show that the respondents of all age groups have little trust in public authorities and in their ability to implement changes, and therefore, the respondents demonstrate insufficient support for voluntary amalgamation of territorial communities. However, the high rate of personal support for community amalgamation at $60.6 \%$ (compared to $27.4 \%$ at the pre-project stage) indicates the success of the reengineering programme. After its completion, the residents of the communities voluntarily formed the Kosmatska and Yabluniv ATCs (December, 2016 and April, 2017, respectively). This confirms that the programme not only had an educational function, but also helped to change the mentality of the residents according to the criteria of the Western institutional matrix, reduce the number of people who resisted amalgamation, and increase the number of supporters of the decentralisation reform. 


\section{Discussion}

The purpose of the research was to demonstrate and explain how the theory of transformative adult learning can be used for a targeted change of the mentality of communities in order to promote democratic governance in Ukraine. We outlined the stages and methodology of the research taking into account the fact that the adult residents of communities do not rely on judgements of representatives of public and local authorities and learn to formulate their common visions of community life, define their common perspectives and activities based on their own values, life experience, education and shared resources. Their worldviews are unconscious frames of reference constructed of habits of the mind which can become so ingrained that it takes a powerful catalyst, a forceful argument to shake them (Christie et al., 2015). The problem, which lies not only in changing individuals' invalid assumption but also their behaviour, can be solved through rational discourse rather than force. In such cases, the use of transformative adult learning provides engagement of individuals in the cognitive processes of critical reflection and self-reflection, intuitive and imaginative explorations of the developmental changes, leading to a deep shift in perspective and habits of mind that are more open, permeable, discriminating, and better justified (Kroth \& Cranton, 2014). From this perspective, transformative learning is an activity of comprehension, a transformation of the frame of references of individuals and their communities (Gorbunova, 2015) which is of utter importance at the present stage of global changes. It needs to be understood much more as a socially embedded and socially constructed phenomenon (Jarvis, 1987). Therefore it is consistent with constructivism as a process of building a better world.

The unity of people who cooperate for the common good is known as one of the priorities of the socalled "progressive capitalism", a term introduced by Stiglitz (2019), a Nobel Prize winner in Economics. He argues that wealth of nations is the result of scientific inquiry (into learning about the world around us) and social organisation that allows large groups of people to work together for the common good (Stiglitz, 2019). If we rephrase this statement, it becomes quite obvious that the wealth of the community can be determined by the unity of three factors: science, education and social organisation of people. In this regard, the innovations in education aim not only at knowledge development but also at the process of knowledgediffusion (Shi-Yong, 2019). Therefore, the implementation of the programme of community development reengineering involved the following sequence of changes: (1) alienation to the generally accepted social roles formed in the context of centralised bureaucratic management; (2) changing the individuals' beliefs about the prospects of decentralisation of power and defining their role in the new reality; (3) reintegration of the individuals with a new vision into the society in order to continue their adaptation and the spread of the new set of beliefs among community members.

Unlike national projects in which we have been actively involved (including TEMPUS "Education for Leadership, Intelligence and Talent Encouraging", DOCCU "Development of Citizenship Competences in Ukraine", Presidential Personnel Reserve "New Elite of the Nation" and others), the project "Aware residents is a Strong Community" was implemented at the lowest level - territorial communities of IvanoFrankivsk region. This made it possible to study thoroughly and promptly the problems that needed to be solved in communities, as well as to bring experts closer to the consumers of educational services.

The main results of the implementation of the programme of community development reengineering are the increase of respondents' knowledge and positive change in their attitude to the reform of decentralisation. The programme changed the mentality of the residents of ATCs and increased the number of supporters of the decentralisation reform and community amalgamation by $33.2 \%$. The important feature of our research is that the results of the programme were not only drawn out from a survey but also proved by the survey participants' further actions. Furthermore, the project contributed to the development of leadership at the local level due to the system-oriented approach. However, evaluating its result in quantitative terms was not the task of the research.

Thus, the results of our study, as well as the results of research of foreign experts (Christie et al., 2015; Taylor, E.W., 2007), empirically proved that transformative learning can be effectively practised for a targeted change in the mentality of adults. Indicators $\Delta \mathrm{R}$ in Table 2 generally confirm the postulate of the theory of transformative adult learning according to which as a result of such learning the attitude of the youngest adults changes the most and the attitude of the oldest ones changes the least. Exceptions to this rule (indicators for criteria "comprehension of the objective reasons for introducing changes to the Constitution of Ukraine" and "recognition of importance of holding public discussions"), in our opinion, are insignificant and do not indicate shortcomings, but integrity in conducting the research.

The research allows us to make the following assumptions:

1. The changes in the mentality of communities achieved through transformative adult learning are one of the prerequisites for obtaining positive results of reforming public administration and introducing 
democratic governance in Ukraine. Transformative adult learning provides reorientation of human resources to autonomous thinking and also makes it possible to implement the ideological patterns of the Western institutional matrix (federal decentralised political system, market economy and individualistic ideology) in the mentality of Ukrainian communities.

2. The key performance indicators which demonstrate the effectiveness of the implementation of the projects and educational programmes, focused on introducing democratic governance in Ukraine, should not be limited to information on the number of training activities and the dynamics of the level of knowledge of their participants, but should also contain information about the change "in people's opinion", their points of view. Such quantitative and qualitative indicators are identified at the pre-project and follow-up surveys. The reliability of the results of the study is substantiated by both the empirical analysis and the achievement of the decentralisation goal - the creation of capable Kosmatska and Yabluniv territorial communities where the reengineering programme was carried out.

3. Solving the problems of social organisation of people for the common good (especially at the regional level) necessitates the development of the intellectual resources not only of the elite but also of the rest of population, which influences decision-making concerning the community development as the basis of local self-government. Furthermore, the content of complex approaches to the implementation of projects and programmes should be substantiated on the basis of empirical research and scientific achievements, which will provide a range of channels for information transmission (web pages, social media, digital books, etc.), as well as permit the adaptation of innovative models, technologies and instruments for training and development of human resources (web-based learning, mobile learning, collaborative experiential learning, etc.). Therefore, in order to transform the mentality of communities at the regional level, in particular, at the level of ATCs, the following aspects should be taken into consideration: scientific inquiry and social organisation of people for the common good as two priorities of progressive capitalism; inclusion of the intellectual resources of elite and population into the economy through the use of innovative models, techniques and instruments for managing the intellect of human resources (Dzvinchuk et al., 2019).

Increasing the efficiency of the transformative adult learning programme should be provided not only by integration of training activity with scientific research but also by strengthening their cultural perspective. To increase the effectiveness of the programme of transformative adult learning, its implementation should not only involve the integration of training activity and scientific research but also strengthen their cultural perspective. In this context, the experience of the GLOBE research project (Global Leadership and Organisational Behavior Effectiveness) is interesting. It was implemented in 1994-2014 as one of the most large-scale and prestigious international management research projects in social sciences with over 200 researchers from 62 countries participating in it (GLOBE, 2014). Their theoretical and empirical research through the item evaluation, Q-sorting, and pilot studies allowed redefining the scientific understanding of the main dimensions of culture in different societies around the world, such as power distance, performance orientations, assertiveness, future orientations, human orientation, institutional collectivism, in-group collectivism, gender egalitarianism, uncertainty avoidance. In 2020 the GLOBE research programme started conducting new surveys in more than 120 countries. We consider it expedient to use their results in the development of theory and practice of transformative adult learning.

\section{Limitations}

The main limitation of our research is that we did not evaluate the additional value of the programme of community development reengineering, such as leadership development by the system-oriented approach due to the lack of valid methods of its evaluation.

\section{Conclusions}

The results of realisation of the reengineering programme for the development of territorial communities in Ukraine "Aware Residents is a Strong Community" oriented to the implementation of the patterns of the Western institutional matrix in the human mentality show the effectiveness of transformative adult learning for a targeted change in the mentality of communities' residents. The use of the approach of individual and collective transformative learning and community engagement approach has ensured local targeted changes in the communitarian ideology. Therefore the finding can be used when implementing programmes aimed at the reformation of public administration and introduction of democratic governance.

The programme of transformative adult learning should include the following sequence of changes: (1) alienation to the generally accepted social roles; (2) changing the individuals' beliefs and defining their roles in the new reality; (3) reintegration of the individuals with a new vision into the society in order to continue their adaptation and the spread of the new set of beliefs among community members. 
The survey found out that the older the target audience, the more difficult it is to change their mentality. Therefore, the performance indicators of programmes of transformative adult learning should be based not only on the data which prove the increase in participants' knowledge of possible solutions of certain community problems but also on the evidence of the attitude change of human resources of different age groups to these problems.

The results of the study will be used by the Department of Public Administration and Management of IFNTUOG in three directions: in-depth study and assessment of the economic, ideological and cultural preferences of human resources of the ATCs in order to determine the needs for the development of mindset reengineering technology; development of instruments for web-based and collaborative experiential learning; and, implementation of the project "Development of competence of Lithuanian and Ukrainian public sector employees using design thinking methodology".

\section{Acknowledgements}

The research started as part of the "Aware Residents is a Strong Community" project supported by the East Europe Foundation in December 2015 - October 2016 and continued within the framework of the joint Ukrainian-Lithuanian R\&D project "Competence Development of Lithuanian and Ukrainian Public Sector Employees Using Design-Thinking Methodology" supported by the Ministry of Education and Science of Ukraine in 2020.

\section{References:}

Baran, M. (2015). Mekhanizmy podolannia oporu dobrovilnomu obiednanniu terytorialnykh hromad [The mechanisms to overcome the resistance to voluntary association of territorial communities]. Theory and practice of public administration and local self-government, 2. Retrived 17 December 2019 from http://nbuv.gov.ua/UJRN/Ttpdu_2015_2_25

Biasin, C. (2018). Transformative Learning: evolutions of the adult learning theory. Phronesis, 3 (7), 5-17. https://doi.org/10.7202/1054404ar

Cabinet of Ministers of Ukraine (2014). Kontseptsiia reformuvannia mistsevoho samovriaduvannia ta terytorialnoi orhanizatsii vlady v Ukraini [The Concept of Reforming Local Self-Government and Territorial Structure of Power]. Legislation of Ukraine. Retrieved 13 December 2019 from https://zakon5.rada.gov.ua/laws/show/333-2014-\%D1\%80?lang=en\#n8

Christie, M., Carey, M., Robertson, A., \& Grainger, P. (2015). Putting transformative learning theory in practice. Australian Journal of Adult Learning, 55 (1), 9-30. Retrived 17 January 2020 from https://files.eric.ed.gov/fulltext/EJ1059138.pdf

Churchill, W. (1041). Blood, sweat, and tears. New York: G. P. Putnam's sons.

Dancheva, O. (2015). Detsentralizatsiia: yak zminiuietsia dumka liudei? [Decentralisation: How does people's opinion change]. DESPRO. Retrieved 7 December 2019 from https://despro.org.ua/news/detail.php?ID=1540

Davis, K. L., Kliewer, B. W., \& Nicolaides, A. (2017). Power and reciprocity in partnerships: deliberative civic engagement and transformative learning in community-engaged scholarship. Journal of Higher Education Outreach and Engagement, 21(1), 30-54. Retrived 10 December 2019 from https://openjournals.libs.uga.edu/jheoe/article/view/1316/1313

Dzvinchuk, D., \& Petrenko, V. (2018). Prosvitnytstvo i detsentralizatsiia [Enlightenment and decentralisation]. In V. Kremen' and N. Nychkalo, (Eds.), Conceptual principles of the adult education development: world experience, Ukrainian realities in perspective (pp. 379-384). Kyiv: Znannia Ukrainy.

Dzvinchuk, D., Petrenko, V., Orliv, M., Mazak, A., \& Ozminska, I. (2019). Progressive capitalism” by J. Stiglitz: rethinking the priorities of its formation. Journal of Business and Economic Development, 4 (4), 128-133. https://doi.org/10.11648/j.jbed.20190404.11

GLOBE (2014). The GLOBE 2020 studies. GLOBE Project. Retrieved 16 January 2020 from https://globe.bus.sfu.ca/

Gorbunova, L. (2015). Osvita dlia doroslykh: kohnityvno-komunikatyvni stratehii i praktyky [Adult Education: Cognitive and Communicative Strategies and Practices]. Unpublished doctoral thesis, Institute of Higher Education NAES of Ukraine, Kyiv, Ukraine.

Hlushko, T. (2017). Ekonomichna teoriia natsii u konteksti hlobalizatsiinykh protsesiv (sotsialno-filosofskyi analiz) [Economic theory of the nation in the context of globalisation processes (socio-philosophical analysis)]. Doctoral thesis, NPDU, Kyiv.

Janiunaite, B. \& Petraite, M. (2015). Diversity of innovation culture profiles in educational organizations across the sector: case of Lithuania. In D. Becker-Pestka and E. Kowalik (Eds.), Wyzwania współczesnej pedagogiki (pp. 73-84). Warszawa: CeDeWu.

Jarvis, P. (1987). Adult learning in the social context. New York: Croom Helm Ltd.

Jin, Z. (2017). A constructivism-based 3D scene display teaching system for Wushu teaching. International Journal of Emerging Technologies in Learning, 12 (1). https://doi.org/10.3991/ijet.v12i01.6485

Kennedy-Reid, Sh. (2014). Towards redefining individual-collective transformative learning: a duality approach. In A. Nicolaides \& D. Holt (Eds.), Spaces of transformation and transformation of space (pp. 332-340). New York: Teachers College, Columbia University.

Kirdina, S. (2014). Institutional Matrices and the Development of Russia: an Introduction to X-Y- theory. St. Petersburg: Nestor-Istoriya. Kroth M., \& Cranton, P. (2014). Stories of transformative learning. Rotterdam: Sense Publishers.

Lelechenko, A., Vasylieva, O., Kuibida, V., \& Tkachuk, A. (2017). Mistseve samovriaduvannia v umovakh detsentralizatsii povnovazhen [Local self-government under conditions of decentralisation of powers]. Kyiv: NADU.

Mezirow, J. (1997). Transformative learning theory to practice. New directions for adult and continuing education, 74, 5-12. https://doi.org/10.1002/ace.7401

Monitoring of process of power decentralisation and local governance reform (2019). Decentralisation. Retrieved 11 January 2020 from https://decentralization.gov.ua/en/mainmonitoring\#main_info 
Panasiuk, R. (2018). Structural and functional model of the amalgameted territorial community as a primary element of the local government system. International Journal of Innovative Technologies in Economy, 1(13), 104-112. Retrieved 18 December 2019 from https://journals.indexcopernicus.com/search/article?articleId=1849731

Panasiuk, R., \& Petrenko, V. (2017). On modification of J. Fogg's model for managing the process of creating amalgamated territorial communities in the Regions of Ukraine. In L. Goral (Ed.), Proc. VI International scientific and practical conference "Theory and practice of strategic management of the development of sectoral and regional social systems"(pp.113-116). Ivano-Frankivsk, Ukraine: IFNTUOG.

Panasiuk, R., Petrenko, V., Popova, H., \& Jasinska, J. (2018). Reengineering the mentality of human resources is a necessary part of the process of successful change management in socio-economic systems. International Journal of Innovative Technologies in Economy, 5(17), 60-68. https://doi.org/10.31435/rsglobal_ijite/01062018/5662

Petrenko, V., Struk, N., \& Kushniriuk, V. (2016). Obiznani meshkantsi - sylna hromada [Aware Residents is a Strong Community]. Ivano-Frankivsk: TzOV "Tsyfrovi tehnolohii druku".

Petrenko, V., Andybur, A., Melnytskyi, M., \& Jasinska, J. (2017). Mental reengineering as a required component of change management in socio-economic and sectoral systems. In L. Goral (Ed.), Proc. VI International scientific and practical conference "Theory and practice of strategic management of the development of sectoral and regional social systems" (pp. 28-30). IvanoFrankivsk: IFNTUOG. Retrieved 18 December 2019 from http://elar.nung.edu.ua/handle/123456789/5693

Poliakova, S. (2017). Detsentralizatsiya vlady v Ukrayini: problemy obyednanykh hromad [Decentralisation of power in Ukraine: problems of united communities]. Economy and Society, 13, 1033-1039. Retrieved 2 December 2019 from https://economyandsociety.in.ua/

Pres-tsentr initsiatyvy "Detsentralizatsiia vlady" (2017). Try roky detsentralizatsii - try roky dii i yakisnykh peretvoren [Three years of decentralization is a three years of action and quality transformation]. Decentralisation. Retrieved 5 December 2019 from https://decentralization.gov.ua/news/4913

Putnam, D. (1993). Making democracy work: civic traditions in modern Italy. New Jersey: Princeton University Press.

Pylynskyi, Ya. (2018). Deliberatyvna osvita v umovakh detsentralizatsii [Deliberative education under decentralization]. Kyiv: "Stylos".

Radchenko, O., \& Molodtsov, O. (2018). The "institutional matrix" methodology on the example of the decentralization of power in Ukraine. In R. Voitovych \& P. Vorona, (Eds.), Scientific and practical support for decentralised service delivery in amalgamated territorial communities (pp. 132-135). Kyiv: IPK DSZU.

Shi-Yong, Z. (2019). The influence of community structure on the diffusion of knowledge - a view based on market segmentation. International Journal of Emerging Technologies in Learning, 14 (8). Retrieved 18 December 2019 from https://onlinejournals.org/index.php/i-jet/article/view/10397

Shubina, I., \& Kulakli, A. (2019). Pervasive leaning and technology usage for creativity development in education. International Journal of Emerging Technologies in Learning, 14(1). Retrieved 24 December 2019 from https://onlinejournals.org/index.php/i-jet/article/view/9067

Stiglitz, E. J. (2019). After Neoliberalism. Project Syndicate. Retrieved 28 December 2019 from https://www.projectsyndicate.org/commentary/after-neoliberalism-progressive-capitalism-by-joseph-e-stiglitz-2019-05?barrier=accesspaylog

Taylor, E.W. (2007). An update of transformative learning theory: a critical review of the empirical research (1999-2005). International Journal of Lifelong Education, 26 (2), 173-191. https://doi.org/10.1080/02601370701219475

Tanasiichuk, O. (2019). Local community development through civic education. Bukovynskyi visnyk derzhavnoi sluzhby ta mistsevoho samovriaduvannia - Bukovyna bulletin of civil service and local self-government, 2, 55-58. Retrieved 25 November 2019 from http://buk-visnyk.cv.ua/news/1469/

Tkachuk, A. (2017). Mistseve samovriaduvannia ta detsentralizatsiia [Local self-government and decentralization]. Kyiv: Lehalnyi status.

Received: February 09, 2020

Accepted: September 15, 2020 